\title{
UNKNOWN PRIMARY TUMOR SITES IN SPINAL METASTASIS
}

\author{
METÁSTASE VERTEBRAL EM TUMOR PRIMÁRIO DE LOCALIZAÇÃO DESCONHECIDA \\ METÁSTASIS VERTEBRAL EN TUMOR PRIMARIO DE LOCALIZACIÓN DESCONOCIDA \\ Priscila Barlle Marchi Candido, ${ }^{1}$ Rômulo Pedroza Pinhelro, ${ }^{2}$ Fernanda Maris Peria, ${ }^{3}$ Vinicius Nogueira Toledo, ${ }^{2}$ Herton Rodrigo Tavares Costa, ${ }^{2}$ \\ Helton luiz Aparecido Defino²
}

1. University of São Paulo, Ribeirão Preto Medical School, Department of Medical Clinics, Ribeirão Preto, SP, Brazil.

2. University of São Paulo, Ribeirão Preto Medical School, Department of Orthopedics and Anesthesiology, Ribeirão Preto, SP, Brazil.

3. University of São Paulo, Ribeirão Preto Medical School, Hematology and Clinical Oncology, Department of Medical Imaging, Clinical Oncology Division, Ribeirão Preto, SP, Brazil.

\begin{abstract}
Objective: The goal of the study was to report the prevalence of spinal metastasis with unknown primary tumor, clinical features, treatment results and patient survival. Methods: A retrospective evaluation of 103 patients with spinal metastasis and epidural compression, who underwent surgical treatment between March 2009 and August 2015. The prevalence of metastatic spinal tumor with unknown primary tumor was evaluated, as well clinical features, survival and treatment results. Results: Of 103 patients with spinal metastasis and epidural compression, seven patients (6.8\%) with unknown primary tumor site were identified; five (71.4\%) male and two (28.6\%) female, with ages ranging from 37 to 67 years (50.7 years). The metastasis was located in the thoracic spine in six of the patients (85.7\%) and in the cervical spine in one (14.3\%). The mean survival time was 44.8 days. Conclusion: Spinal metastasis with unknown primary tumor was found in $6.8 \%$ of patients. The prognosis and outcomes were poor, and patients had poor survival rates. Level of evidence III; Experimental study.
\end{abstract}

Keywords: Neoplasm Metastasis; Spine; Unknown Primary Neoplasms.

\section{RESUMO}

Objetivo: O objetivo deste estudo foi relatar a prevalência de metástases vertebrais em tumores primários desconhecidos, suas características clínicas, resultados do tratamento e sobrevida dos pacientes. Métodos: Avaliação retrospectiva de 103 pacientes com metástase da coluna vertebral e compressão epidural, submetidos a tratamento cirúrgico entre março de 2009 e agosto de 2015. Avaliou-se a prevalência de tumores metastáticos vertebrais com tumor primário desconhecido, assim como as características clínicas, a sobrevida e os resultados do tratamento. Resultados: Dos 103 pacientes com metástase vertebral e compressão epidural, foram identificados sete pacientes (6,8\%) com tumor primário de origem desconhecida; cinco pacientes (71,4\%) eram do sexo masculino e dois pacientes (28,6\%) do sexo feminino, com idades variando de 37 a 67 anos (50,7 anos). A localização da metástase vertebral era na coluna torácica em seis pacientes (85,7\%) e na coluna cervical em um paciente (14,3\%). A média de sobrevida dos pacientes foi de 44,8 dias. Conclusões: As metástases vertebrais com tumor primário de origem desconhecida foram observadas em 6,8\% dos pacientes. O prognóstico e os resultados foram ruins, e os pacientes tiveram sobrevida bastante baixa. Nível de evidencia III; Estudo Comparativo Retrospectivo.

Descritores: Metástase Neoplásica; Coluna Vertebral; Neoplasias Primárias Desconhecidas.

\section{RESUMEN}

Objetivo: El objetivo de este estudio fue relatar la prevalencia de metástasis vertebrales en tumores primarios desconocidos, sus características clínicas, resultados del tratamiento y sobrevida de los pacientes. Métodos: Evaluación retrospectiva de 103 pacientes con metástasis de la columna vertebral y compresión epidural, sometidos a tratamiento quirúrgico entre marzo de 2009 y agosto de 2015 . Se evaluó la prevalencia de tumores metastásicos con tumor primario desconocido, así como las características clínicas, la sobrevida y los resultados del tratamiento. Resultados: De los 103 pacientes con metástasis vertebral y compresión epidural, fueron identificados siete pacientes (6,8\%) con tumor primario de origen desconocido; cinco pacientes (71,4\%\%) eran del sexo masculino y dos (28,6\%) del sexo femenino, con edades variando de 37 a 67 años (50,7 años). La localización de la metástasis vertebral era en la columna torácica en seis pacientes (85,7\%) y en la columna cervical en un paciente (14,3\%). El promedio de sobrevida de los pacientes fue de 44,8 días. Conclusiones: Las metástasis vertebrales con tumor primario de origen desconocido fueron observadas en 6,8\% de los pacientes. El pronóstico y los resultados fueron malos y los pacientes tuvieron sobrevida bastante baja. Nivel de evidencia III; Estudio Comparativo Retrospectivo.

Descriptores: Metástasis de la Neoplasia; Columna Vertebral; Neoplasias Primarias Desconocidas.

\section{INTRODUCTION}

The most common sites for metastases are the lung and liver, followed by the skeletal system. ${ }^{1-3}$ The spine is the site of $80 \%$ of all skeletal metastasis and the thoracic segment is the portion most affected, followed by the cervical and lumbar segments. ${ }^{4}$ The most common primary tumor sites identified in patients with spinal metastasis are the lungs, the breasts and the prostate. ${ }^{2-4}$ However, the primary tumor site cannot always be identified. ${ }^{5,6}$ 
Confirmation of metastasis by biopsy in the absence of an identifiable primary site after complete medical history and physical examination, laboratory investigation, computed tomography of the chest and abdomen, endoscopy, colonoscopy, mammography and additional studies is defined as unknown primary tumor (UPT). ${ }^{5-7}$ Even in autopsy, the primary tumor cannot be identified in $30 \%$ of patients. ${ }^{6}$ UPT do not present the classical correlation between the site of metastasis and the origin of the tumor. When identified, they are small and asymptomatic in the majority of patients. A short medical history, rapid disease progression, and metastasis to different sites expresses the specific biology of UPT. ${ }^{7}$ The primary site is identified in $25 \%$ of living patients, and at autopsy in $70 \% .^{6-7}$

The aim of the study was to report the prevalence of UPT in patients who underwent surgical treatment of spinal metastasis with epidural compression, as well as the clinical features, outcomes and patient survival

\section{METHODS}

The study was approved by local IRB - no. 6513/2015. A retrospective review was performed of 103 patients with spinal metastasis with epidural compression who underwent surgical treatment. The informed consent (IC) was waived, as it is an observational and retrospective study. The patients underwent surgery at the Department of Orthopedics and Anesthesiology between March 2009 and August 2015. Patients with a diagnosis of hematological malignancy were not enrolled in the study.

The surgical procedure consist of posterior fixation and decompression. Anterior column reconstruction was performed using cage and bone cement in patients with severe vertebral body involvement and instability. Thoracic spine anterior reconstruction was performed by the posterior approach, and cervical spine reconstruction by the combined anterior approach. (Figures 1 and 2)

The demographic data, clinical features, evaluation of surgical treatment, and survival of patients with spinal metastasis and unknown primary tumors were recorded. (Tables 1 and 2)

\section{RESULTS}

Of the 103 evaluated patients, seven (6.8\%) were identified as having unknown primary tumor. (Table 1 )

Five $(71.4 \%)$ of these patients were male and two (28.6\%) female, with ages ranging from 37 to 67 years (mean 50.7 years). In five (71.4\%) patients, the initial symptoms were related to spinal metastasis and there was no previous diagnosis of cancer. Most of the metastatic lesions were on thoracic spine (six patients) and just one was in the cervical spine. On imaging evaluation, four (57.1\%) patients had multiple metastatic lesion and three $(42.8 \%)$ a
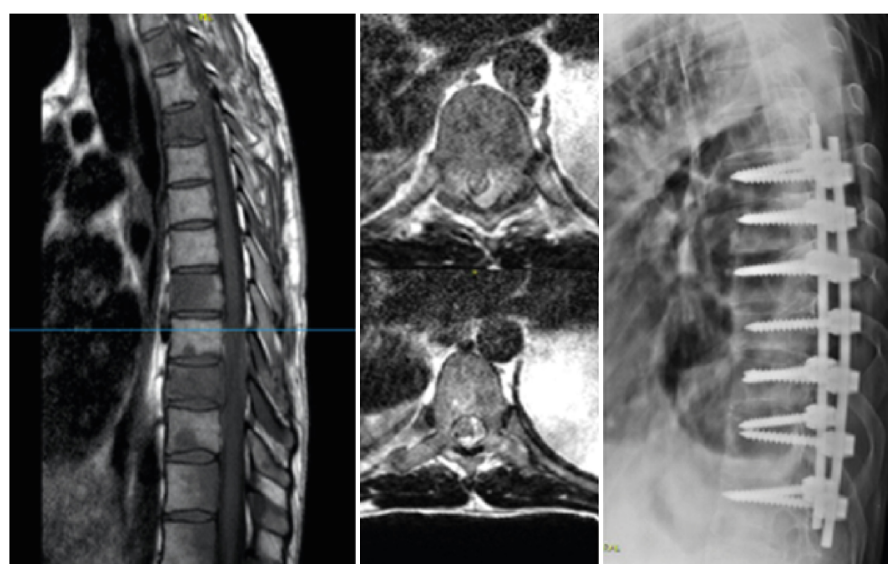

Figure 2. Male, 37 years old - multiple thoracic lesion, Frankel A. Surgica stabilization with pain improvement, one degree of neurological improvement (A/B), Death 30 days after surgery due to pneumonia (Patient no. 1, Table 2).

Table 1. Distribution of primary tumors in patients with spinal metastasis and epidural compression (HCFMRP-USP 2009 to 2015).

\begin{tabular}{|c|c|c|c|}
\hline \multirow{3}{*}{ Primary tumor } & \multicolumn{2}{|c|}{ Sex } & \multirow{3}{*}{$\begin{array}{c}\text { Total } \\
\text { n (\%) }\end{array}$} \\
\hline & Male & Female & \\
\hline & n (\%) & n (\%) & \\
\hline Adrenal & $1(1,59)$ & $0(0,00)$ & $1(0,97)$ \\
\hline Bladder & $2(3.17)$ & $0(0.00)$ & $2(1.94)$ \\
\hline Oral cavity & $3(4.76)$ & $1(2.50)$ & $4(3.88)$ \\
\hline Cervix & $0(0.00)$ & $2(5.00)$ & $2(1.94)$ \\
\hline Colon & $2(3.17)$ & $1(2.50)$ & $3(2.91)$ \\
\hline Esophagus & $1(1.59)$ & $0(0.00)$ & $1(0.97)$ \\
\hline Small intestine & $1(1.59)$ & $0(0.00)$ & $1(0.97)$ \\
\hline Breast & $0(0.00)$ & $27(67.50)$ & $27(26.21)$ \\
\hline Choroid plexus melanoma & $1(1.59)$ & $0(0.00)$ & $1(0.97)$ \\
\hline Nasopharynx & $1(1.59)$ & $0(0.00)$ & $1(0.97)$ \\
\hline Oropharynx & $1(1.59)$ & $0(0.00)$ & $1(0.97)$ \\
\hline Prostate & $23(36.51)$ & $0(0.00)$ & $23(22.33)$ \\
\hline Lung & $4(6.35)$ & $1(2.50)$ & $5(4.85)$ \\
\hline Rectum & $3(4.76)$ & $2(5.00)$ & $5(4.85)$ \\
\hline Kidney & $3(4.76)$ & $0(0.00)$ & $3(2.91)$ \\
\hline Sarcoma & $7(11.11)$ & $1(2.50)$ & $8(7.77)$ \\
\hline Maxillary sinus & $1(1.59)$ & $0(0.00)$ & $1(0.97)$ \\
\hline Unknown primary & $5(7.94)$ & $2(5.00)$ & $7(6.80)$ \\
\hline Testicle & $2(3.17)$ & $0(0.00)$ & $2(1.94)$ \\
\hline Thyroid & $2(3.17)$ & $2(5.00)$ & $4(3.88)$ \\
\hline Gallbladder & $0(0.00)$ & $1(2.50)$ & $1(0.97)$ \\
\hline Total & $63(100.00)$ & $40(100.00)$ & $103(100.00)$ \\
\hline
\end{tabular}
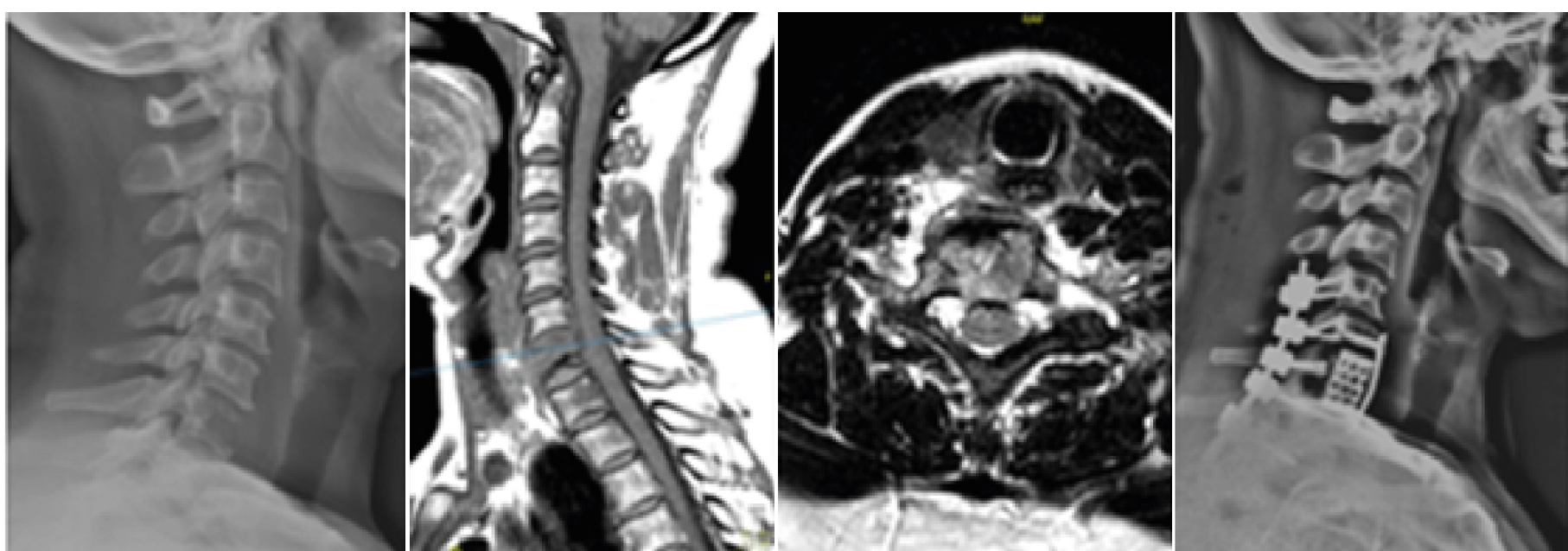

Figure 1. Female, 49 years old - lesion at C6, Frankel E. Anterior corpectomy and posterior fixation. Pain improvement, normal neurological function (E) and death 78 days after surgery (Patient no. 4, Table 2) 
Table 2. Demographic and clinical features.

\begin{tabular}{c|c|c|c|c|c|c|c|c|c|c}
\hline Age & Sex & Localization & Lesion & $\begin{array}{c}\text { Visceral } \\
\text { metast. }\end{array}$ & Frankel pre & $\begin{array}{c}\text { Frankel } \\
\text { post }\end{array}$ & $\begin{array}{c}\text { Pain } \\
\text { improvement }\end{array}$ & Tomita score & Tokuhashi & Survival (days) \\
\hline 37 & M & Thoracic & Multiple & Liver & A & B & Yes & 8 & 4 & 30 \\
\hline 55 & M & Thoracic & Multiple & Liver & E & E & No & 8 & 6 \\
\hline 53 & M & Thoracic & Single & None & B & B & Yes & 8 & 22 \\
\hline 49 & F & Cervical & Single & Liver & E & E & Yes & 8 & 6 & 34 \\
\hline 43 & M & Thoracic & Multiple & Lung & C & C & Yes & 10 & 3 & 78 \\
\hline 51 & F & Thoracic & Multiple & Liver & E & E & No & 4 & 6 & 33 \\
\hline 67 & M & Thoracic & Single & None & B & C & No & 3 & 11 & 41 \\
\hline
\end{tabular}

solitary lesion. Five patients $(71.4 \%)$ presented visceral metastasis. The patient demographic is shown in Table 2.

The neurological deficit, according to the Frankel Scale ${ }^{8}$ is illustrated on Table 2. Four (57.1\%) patients presented neurological deficit and three (42.8\%) were neurologically normal. After surgery, two (28.6\%) patients had improvement of one degree and five $(71.4 \%)$ maintained the preoperative neurological function. Pain was improved in four $(57.1 \%)$ patients. Survival times ranged from 22 to 78 days (mean 44.8\%), with deaths occurring due to pneumonia in three patients, and urinary tract infection followed by sepsis in one patient.

The Tokuhashi ${ }^{9}$ and Tomita $^{10}$ scores are shown in Table 2. Based on the Tomita scores, the treatment goals were terminal care in five patients (8-10 prognostic score), medium-term local control in one patient, and long-term local control in 1 patient. Based on the Tokuhashi score six patients required palliative care and one palliative surgery (Table 2)

\section{DISCUSSION}

Approximately $5 \%$ of all newly diagnosed cancers are classified as carcinomas of unknown primary tumor, i.e. systemic metastatic disease without any identifiable primary tumor. ${ }^{11,12}$ It appears that this type of cancer metastasizes before the primary tumor has had time to develop into a macroscopic lesion. ${ }^{7,12,13}$

We found this type of cancer in $6.8 \%$ of the studied group of patients with spinal metastasis with epidural compression. The clinical features of our patients was in accordance with the literature; the tumor was more frequent in males, located in the thoracic spine, and had aggressive evolution and poor prognosis. ${ }^{14}$

The spine has been reported as the most common site of unknown primary tumor metastasis ${ }^{13-15}$ and $11.1 \%$ to $14.5 \%$ of patients with spinal metastasis, and UPT has been found in series of patient with spinal metastasis. ${ }^{13,16,17}$ However, in a large retrospective analysis of 286 patients with unknown bone metastasis, two third had multiple bone lesions without differences in localization. A solitary bone metastasis was observed in $32.5 \%$ of patients. ${ }^{17}$

The most common form of metastasis found in the majority of cancer involves the spread of cancer cells from a primary tumor to surrounding tissues and distant organs. This form is the primary cause of cancer morbidity and mortality. ${ }^{14,18}$ The cells detach from the primary tumor, intravasate into the circulatory and lymphatic systems, evade immune attack, extravasate at distant capillary beds, and invade and proliferate in distant organs. ${ }^{14}$ The biological mechanism underlying tumors of unknown origin are still poor understood. ${ }^{13,14}$ The two main theories used to explain the biology of UPT are: that the cancer cells involute irrespective of the development of metastasis (burned-out theory), and the possibility of the existence of a peculiar progenitor cell, or quiescent cell, which may be the cell of origin of the site of metastasis. ${ }^{18}$ It is a clinical challenge to identify a common etiological factor for UPT, as it is a group of heterogeneous neoplasia with different histotypes. ${ }^{13-19}$

In most of our patients (five out seven) the symptoms related to spinal metastasis were the initial clinical manifestation of cancer, and three of the patients presented severe neurological deficit. Metastatic spinal cord compression affects approximately $2.5 \%$ to $5 \%$ of all patients with cancer. It is most common in patients with known cancer, and it may also be the initial manifestation of UPT. ${ }^{20-22}$ We were faced with a diagnostic and therapeutic problem, as a treatment decision was needed before the final primary diagnosis of the tumor could be obtained. Patients with UPT may have a different treatment outcome, ${ }^{20}$ but it was impossible to perform the diagnosis before starting surgical treatment that would allow biopsy of the lesion. Transpedicular biopsy of the affected vertebral level allows an additional diagnosis of primary carcinoma in $8 \%$ of patients, after a thorough investigation including history, clinical examination, laboratory tests, and CT scans of the chest, abdomen, pelvis and bone scan. ${ }^{15-16}$

Palliative or radical surgery has been widely performed in patients with spinal metastasis, to improve pain, neural function and quality of life, and satisfactory results have been reported. ${ }^{22,23}$ In general, the tumor pathology, overall functional status, neurological status and overall burden of disease have been considered as prognostic factors. ${ }^{3,4,15}$ However, the prognosis differs in patients whose primary tumor is unknown. ${ }^{23,24}$

The diagnosis workup to find the primary tumor is very important, as it is of great value in selecting the best treatment option. ${ }^{16}$ Adjuvant therapy on sensitive tumors leads to longer patient survival; ${ }^{25}$ however UPT are aggressive and poorly-differentiated; there is no therapy available, they have poor patient survival, and the diagnosis cannot be performed without biopsy. ${ }^{25-27}$

The survival rates of our patient with UPT were lower than the recommended life expectancy limit of 3-6 months for surgical treatment of spinal metastasis, ${ }^{15,17,20}$ but it was impossible to determine a diagnosis of UPT without performing biopsy, which is done during the surgical procedure to decompress and stabilize the affected vertebral segment. Even in patients without neurological deficit, we performed surgical stabilization to improve pain, function or patient care. Pain improvement was achieved in $77.14 \%$ of our patients. Considering pain improvement and patient care, it would not be the best approach to start with biopsy and postpone the stabilization of the affected vertebral segment. On the other hand, surgical procedures were performed in patients with short survival prognoses. Our current approach is to perform biopsy before the surgical treatment whenever possible, in order to avoid surgery in patients with short survival prognoses.

We did not observe good agreement between the Tokuhashi and Tomita scores and patient survival, and the indication for surgical treatment was not based in these scales. We observed agreement of these scales only for patient with less than six months survival and retrospectively the use of these scales in UPT patients could have avoid surgery in patients with short survival. However, it was not possible to predict survival because it was impossible to perform biopsy before surgical treatment for stabilization and decompression of the affected vertebral segment.

Bone metastasis from unknown tumor has a poor prognosis, and patients with spinal metastasis have short survival times. ${ }^{13,17}$ The reported survival times for metastatic spinal UPT ranged from 2.6 to 11 months..$^{26,27}$ We observed short survival times in our patients, and death occurred in 4 patients shortly after surgery, due to pneumonia in three patients and sepsis in one. But survival was short even in patients with no postoperative complications. UPT metastasis had a very aggressive clinical course, with poor prognosis., 6, 29

The limitations of this study are as follow: it is a retrospective study, with a small number of patients enrolled, and it only enrolled those with spinal metastasis with epidural compression who underwent surgery, which is a subset among spinal metastasis 
patients. Specific and deep histological and immunohistochemical staining was not considered when studying the unknown primary tumor, and neither were advances in imaging studies, since the study was performed between 2009 and 2015. UPT are often classified as adenocarcinomas, squamous cell carcinomas, poorly-differentiated carcinoma, and neuroendocrine carcinomas ${ }^{11,12,29}$ but it was not possible to perform this classification in our patients.

\section{CONCLUSIONS}

UPT is a diagnostic and therapeutic challenge and there are few available evidence-based indications for work-up and treatment.
It is still controversial whether the prognosis would be improved with identification of the UPT. The results and survival of our patients with spinal metastasis and UPT were very disappointing, and were associated with a high cost. Screening and early diagnosis of UPT are impossible by definition, and there are delays in diagnosing and staging the disease. The treatment is challenging, with a poor prognosis and outcomes.

All authors declare no potential conflict of interest related to this article.

CONTRIBUTION OF THE AUTHORS: Each author made significant individual contributions to this manuscript. PBMC and FMP: article design, statistical analysis, project design and writing; RPP and VNT: article design, statistical analysis and review; HRTC: data collection and review; HLAD: article design, project design, statistical analysis, writing and review.

\section{REFERENCES}

1. Mattana JL, Freitas RR, Mello GJP, Armani Neto M, Freitas Filho G, Ferreira CB, et al. Estudo da aplicabilidade do escore de Tokuhashi modificado nos pacientes tratados cirurgicamente de metástases vertebrais. Rev Bras Ortop. 2011:46(4):424-30. doi: 10.1590/S010236162011000400014

2. Valesin Filho ES, Tardini R, Abreu LC, Motter BV, Adami F, Rodrigues LMR. Estudo epidemiológico de 55 pacientes portadores de doença vertebral metastática sintomática em Santo André - SP, Brasil. Coluna/Columna. 2013;12(1)32-5. doi: 10.1590/S180818512013000100007

3. Cortez PR. Spinal metastasis: diagnosis, treatment and prognosis: integrative review from 2012 to 2017. Coluna/Columna. 2020;19(1):58-66. doi: 10.1590/s1808 185120201901192641

4. Sutcliffe P, Connock M, Shyangdan D, Court R, Kandala NB, Clarke A. A systematic review of evidence on malignant spinal metastases: natural history and technologies for identifying patients at high risk of vertebral fracture and spinal cord compression. Health Technol Assess. 2013;17(42):1-274. doi: 10.3310/hta17420

5. Abbruzzese JL, Abbruzzese MC, Lenzi R, Hess KR, Raber MN. Analysis of a diagnostic strategy for patients with suspected tumors of unknown origin. J Clin Oncol. 1995;13(8):2094103. doi: $10.1200 / J C O .1995 .13 .8 .2094$

6. Nystrom JS, Weiner JM, Heffelfinger-Juttner J, Irwin LE, Bateman JR, Wolf RM. Metastatic and histologic presentations in unknown primary cancer. Semin Oncol. 1977;4(1):53-8.

7. Hillen HF. Unknown primary tumours. Postgrad Med J. 2000;76(901):690-3. doi: 10.1136/ pmj.76.901.690

8. Frankel HL, Hancock DO, Hyslop G, Melzak J, Michaelis LS, Ungar GH, et al. The value of postural reduction in the initial management of closed injuries of the spine with paraplegia and tetraplegia. Part I. Paraplegia. 1969;7(3):179-92. doi: 10.1038/sc.1969.30

9. Tokuhashi $Y$, Matsuzaki H, Oda H, Oshima M, Ryu J. A revised scoring system for preoperative evaluation of metastatic spine tumor prognosis. Spine (Phila Pa 1976). 2005:30(19):2186-91. doi: 10.1097/01.brs.0000180401.06919.a5

10. Bauer H, Tomita K, Kawahara N, Abdel-Wanis ME, Murakami H, Akamura T. Surgical strategy for spinal metastases. Spine (Phila Pa 1976). 2002;27(10):1124-6. doi: 10.1097/00007632-200102010-00016

11. Pavlidis N. Fizazi K. Carcinoma of unknown primary (CUP). Crit Rev Oncol Hematol. 2009;69(3):271-8. doi: 10.1016/j.critrevonc.2008.09.005

12. Carlson HR. Carcinoma of unknown primary: searching for the origin of metastases. JAAPA 2009:22(8):18-21.

13. Argentiero A, Solimando AG, Brunetti O, Calabrese A, Pantano F, luliani M, et al. Skeletal metastases of unknown primary: biological landscape and clinical overview. Cancers (Basel). 2019;11(9):1270. doi: 10.3390/cancers 11091270

14. Seyfried TN, Huysentruyt LC. On the origin of cancer metastasis. Crit Rev Oncog. 2013;18(12):43-73.

15. Piccioli A, Maccauro G, Spinelli MS, Biagini R, Rossi B. Bone metastases of unknown origin: epidemiology and principles of management. J Orthop Traumatol. 2015;16(2):81-6. doi: 10.1007/s10195-015-0344-0

16. Paholpak P, Sirichativapee W, Wisanuyotin T, Kosuwon W, Jeeravipoolvarn P. Prevalence of known and unknown primary tumor sites in spinal metastasis patients. Open Orthop J. 2012;6:440-4. doi: 10.2174/1874325001206010440

17. Takagi T, Katagiri $H$, Kim Y Suehara $Y$, Kubota $D$, Akaike $K$ et al Skeletal metastasis of unknown primary origin at the initial visit: a retrospective analysis of 286 cases. PLoS One. 2015;10(6):1-17. doi: 10.1371/journal.pone.0129428. eCollection 2015

18. Conway AM, Mitchell C, Kilgour E, Brady G, Dive C, Cook N. Molecular characterisation and liquid biomarkers in Carcinoma of Unknown Primary (CUP): taking the ' $U$ ' out of 'CUP'. Br J Cancer. 2019;120(2):141-53.

19. Katagiri $H$, Takahashi M, Inagaki J, Sugiura $H$, Ito $S$, Iwata $H$. Determining the site of the primary cancer in patients with skeletal metastasis of unknown origin: a retrospective study. Cancer. 1999;86(3):533-7. doi: 10.1002/(sici)1097-0142(19990801)86:3<533::aidcncr24>3.0.co;2-1

20. Loblaw DA, Laperriere NJ, Mackillop WJ. A population-based study of malignant spina cord compression in Ontario. Clin Oncol (R Coll Radiol). 2003;15(4):211-7. doi: 10.1016/ s0936-6555(02)00400-4

21. Schiff D, O'Neill BP. Suman VJ. Spinal epidural metastasis as the initial manifestation of malignancy: clinical features and diagnostic approach. Neurology. 1997;49(2):452-6. doi: 10.1212/wnl.49.2.452

22. Andrade Neto J, Fontes BPC, Macedo RD, Simões CE. Patients with spinal metastasis submitted to neurological decompression and stabilization. Coluna/Columna. 2016;15(3):230-4. doi:10.1590/S1808-185120161503147903

23. Oliveira Junior AV, Bortoletto A, Rodrigues LCL. Avaliação do tratamento cirúrgico nos pacientes com metástase vertebral secundária ao carcinoma de mama. Coluna/Columna. 2012;11(3):226-9. doi: 10.1590/S1808-18512012000300008

24. Destombe C, Botton E, Le Gal G, Roudaut A, Jousse-Joulin S, Devauchelle-Pensec V, et al. Investigations for bone metastasis from an unknown primary. Joint Bone Spine. 2007;74(1):85-9. doi: 10.1016/j.jbspin.2006.05.009

25. Wänman J, Grabowski $P$, Nyström $H$, Gustafsson $P$, Bergh A, Widmark A, et al. Metastatic spinal cord compression as the first sign of malignancy. Acta Orthop. 2017;88(4):457-62. doi: 10.1080/17453674.2017.1319179

26. Enkaoua EA, Doursounian L, Chatellier G, Mabesoone F, Aimard T, Saillant G. Vertebral metastases: a critical appreciation of the preoperative prognostic tokuhashi score in a series of 71 cases. Spine (Phila Pa 1976). 1997;22(19):2293-8. doi: 10.1097/00007632199710010-00020

27. Rades D, Fehlauer F, Veninga T, Stalpers LJA, Basic H, Hoskin PJ, et al. Functional outcome and survival after radiotherapy of metastatic spinal cord compression in patients with cancer of unknown primary. Int J Radiat Oncol Biol Phys. 2007;67(2):532-7. doi: 10.1016/j. ijrobp.2006.08.047

28. Anzuatégui PR, Cunha LAMD, Mello GJP, Stieven Filho E, Graells XS. Spinal Metastasis Surgery: A proposal for a predictive model of morbidity and mortality. Rev Bras Ortop. 2019;54(6):665-72. doi: 10.1055/s-0039-1697018

29. Kim LD, Bueno FT, Yonamine ES, Próspero JD, Pozzan G. Bone metastasis as the first symptom of tumors: role of an immunohistochemistry study in establishing primary tumor. Rev Bras Ortop. 2018;53(4):467-71. doi:10.1016/j.rboe.2018.05.015. 